\title{
"We're Going To Miss You on the Court Because We Need You."
}

The Antagonists: Hugo Black, Felix Frankfurter and Civil Liberties in Modem America. By James F. Simon.* New York: Simon and Schuster, 1989. Pp. 312. $\$ 19.95$

\section{Louis H. Pollak†}

"Adversaries" might well have been a better word. It would have carried less of a connotation of mutual animosity than "antagonists"-the key word in the title of the recent book, The Antagonists: Hugo Black, Felix Frankfurter and Civil Liberties in Modern America, by James F. Simon, Dean of New York Law School. ${ }^{1}$ To be sure, "antagonists" seems to be a time-honored catchword for the relationship between the two great Justices whose competing philosophies shaped the development of American constitutional law for over two decades-from the late 1930's to the early 1960's. Max Freedman wrote in 1967 that "Black and Frankfurter have often been put in opposition to one another as antagonists on the Supreme Court." But Freedman went on to make clear that this popular conception was in some sense a misconception, leaving out the "actual fact, that their judicial differences never hampered their mutual respect and long friendship." And this "actual fact" is one of the very gratifying-indeed, very moving - themes (albeit a secondary one) of Dean Simon's insightful book.

The major themes canvassed by Simon are the large issues which dominated the Court's agenda in the Black-Frankfurter years, most of which are with us still: the scope of the First Amendment's speech and religion guaranties; the "incorporation" of the Bill of Rights into the Fourteenth Amendment; the impact of national security, as perceived by the executive and legislative branches, on the readiness of the judicial branch to protect individual liberty; the capacity of courts to overturn race-defined barriers to equality before the law; modes of accommodating judicial avoidance of

\footnotetext{
* Dean, New York Law School.

$\dagger$ United States District Judge for the Eastern District of Pennsylvania.

1. J. Simon, The Antagonists: Hugo Black, Felix Frankfurter and Givil Liberties in MODERn AMierica (1989) [hereinafter by page only].

2. M. Freedman, Roosevelt and Frankfurter: Their Correspondence, 1928-1945, at $458(1967)$.
} 
"political questions" with judicial protection of a citizen's entitlement to participate in the electoral process on a free and equal basis. On most of these issues the two Justices disagreed. On one-race-they agreed.

Presumably for the reason that Simon intended his work for popular consumption, he has not attempted the elaborate doctrinal analysis that, quite properly, characterizes most of the extensive literature on the two Justices. Simon's book offers far less grist for the mill of constitutional theory than, for example, Professor Wallace Mendelson's Justices Black and Frankfurter: Conflict in the Court, ${ }^{3}$ published almost thirty years ago. On the other hand, Simon is markedly successful in portraying the two Justices as flesh-and-blood people, and in placing them in the context of the social and political forces that brought them to prominence, led them to the Court, and gave texture, nuance and vitality to the cases, great and small, which were their common intellectual fare for so many years. Thus, the first third of Simon's book consists of two profiles which bring the remarkable-and wholly dissimilar-pre-Court careers of the two protagonists to the fore.

"Felix" is a vivid retelling of the relatively familiar story of the immigrant boy who succeeded impressively at City College and Harvard Law School; who, as a young government lawyer, was apprenticed to Henry Stimson in New York and Washington; who became a protegé of Brandeis; who returned to Harvard as a professor, only to take leave during World War I for further public service; who, while back in Washington, became friendly with Assistant Secretary of the Navy Franklin D. Roosevelt; who, again ensconced in Cambridge, continued to immerse himself in public issues, most notably the Sacco-Venzetti case, in ways calculated to outrage the Harvard establishment; and who, during the New Deal, was an academic eminence grise and endless supplier of talent for his old friend, the President of the United States. ${ }^{4}$

"Hugo" is an equally compelling and less familiar story of the Alabama boy who grew up in Ashland (population 350), the county seat of Clay County, where his father ran the general store; who was pushed by his mother to study medicine, but forsook medicine for law; who, in 1915, as a young county prosecutor, sparked a grand jury investigation of appalling police third-degree methods, mostly directed at blacks; who soon became one of Alabama's most successful personal injury lawyers, earning over $\$ 40,000$ in 1925; who joined the Ku Klux Klan in 1923, was elected to the Senate with Klan support in 1926, and then resigned from the

3. W. Mendelson, Justices Black and Frankfurter: Conflict in the Court (1966). The first edition of Mendelson's book appeared in 1961, a year before Justice Frankfurter retired; the second edition appeared in 1966, a year after the Justice's death. Mendelson's doctrinal discussion swept more broadly than Simon's does. Not limiting himself to civil liberties issues, Mendelson examined the Justices' contrasting positions on federalism and on separation of powers as well.

4. Pp. 21-65. 
Klan; who was reelected in 1932 and soon became one of the new President's legislative stalwarts, even going down the line for Roosevelt in support of the Court-packing plan. ${ }^{5}$

\section{Appointments to the Court}

In February of 1937, Franklin Roosevelt, flushed with his landslide reelection and smarting from the Court's repeated rebuffs to key elements of his New Deal program, unveiled his ill-conceived and ill-fated Courtpacking plan-a plan which Senator Black embraced and Professor Frankfurter neither disavowed nor championed. Within a matter of weeks, the judicial ground had markedly shifted-West Coast Hotel v. Parrish $^{8}$ and NLRB v. Jones and Laughlin ${ }^{7}$ seemed to signal new departures. And by the end of the Court's term Justice Van Devanter had retired, reducing the Four (judicial) Horsemen to three. With his first opportunity to make a Supreme Court appointment, Roosevelt appeared to be on the brink of achieving by attrition the new Court that he was still pressing Congress to manufacture by adding Justices. Roosevelt announced that he would nominate Senator Joseph T. Robinson of Arkansas to Van Devanter's seat; but in July the aging majority leader suddenly died, and the Court-packing plan died as well. ${ }^{8}$ On August 11, Roosevelt asked the senior Senator from Alabama to visit him at the White House, and the two reportedly had the following exchange:

"Hugo, this is a form for the nomination of a Supreme Court Justice. May I fill in your name?" Black replied, "Mr. President, are you sure that I'll be more useful in the Court than in the Senate?" "Hugo, I wish you were twins because [Alben] Barkley says he needs you in the Senate; but I think you'll be more useful on the Court."

Frankfurter was one of those who strongly applauded the President's

5. Pp. 66-100. The "Hugo" profile is of particular value becase no one has yet produced a fullscale biography of Justice Black. To be sure, there are touching and insightful family memoirs. See the book by Hugo Black, Jr., MY FATHER: A Remembrance (1973), and the book by Elizabeth De Meritte Black, the Justice's second wife, and Hugo Black, Jr., Mr. Justice and Mrs. BLACK: The Mfemoirs of Hugo L. Black and Elizabeth Black (1986). See also the many references to the Justice and his first wife, Josephine Black, in the autobiography of Virginia Foster Durr, Josephine Black's sister, Outside THE MAGic CrRcle (1985).

The one biographical treatment of Frankfurter, Michael E. Parrish's Felix Frankfurter and His TIMES: The Reform YeARs (1982), is a valuable and comprehensive study of Frankfurter's life up to his appointment to the Court; Parrish's further volume on the Court years will complete the biography.

6. 300 U.S. 379 (1937).

7. 301 U.S. 1 (1937).

8. Schlesinger, Franklin D. Roosetell, in 3 Encyclopedia of THE AMERICAN Constitution 1605, 1607 (L. Levy, K. Karst \& D. Mahoney eds. 1986) [hereinafter ENCYCLOPEdIA].

9. Frank, Hugo L. Black, in 3 The Justices of the Supreme Court of the United States 2321, 2322 (L. Friedman \& F. Israel eds. 1986). 
choice. Confirmation swiftly followed. But before Black took his seat on the Court in the fall of 1937, he had to contend with a fire-storm that greeted disclosure in the national press of his decade-earlier, politically expedient, and brief membership in the Klan. Black, a skilled orator, confronted the dragon of the past in a radio address. The President judged the address " 'a grand job,' .... . 'It did the trick. You just wait and see." "10 Roosevelt's political judgment-which had gone awry with the Gourt-packing plan-was once again on target.

In January of 1938, three months after Black took his seat, Justice Sutherland retired. To that vacancy Roosevelt appointed his Solicitor General, Stanley Reed. In the summer of 1938, Justice Cardozo died. In conversation a few weeks later, the President told his friend Frankfurter that he could not appoint him to the Court; politics required appointment of somebody from west of the Mississippi, and he asked Frankfurter's advice about a number of possible candidates. Months passed with no nomination. Then - as Frankfurter was later to recall-on the evening of January 4, 1939, the following took place:

While I was dressing, while I was in my B.V.D.'s, the door bell rang at 192 Brattle Street, and my wife was going down. We had a guest for dinner, Professor Robert Morse Lovett of the University of Chicago who is a very, very punctual man. It was seven o'clock. My wife all dressed was going down, and here I was in my B.V.D.'s. She said, "Please hurry! You're always late." Just then while I had this conjugal injunction the telephone rang. I went to the telephone. My study was right across the hall, opposite our bed room. The telephone rang, and there was the ebullient, the exuberant, resilient warmth-enveloping voice of the President of the United States, "Hello. How are you?" "I'm fine. How are you?" "How's Marion?" "Fine." "You know, I told you I don't want to appoint you to the Supreme Court of the United States." I said, "Yes." I no more expected the denouement of this conversation. You know, he was given to teasing. Some people said that it was an innocently sadistic streak in him. He just had to have an outlet for fun. "I told you I can't appoint you to the Supreme Court." "Yes, you told me that." "I mean this. I mean this. I don't want to appoint you to the Supreme Court." Here I was in my B.V.D.'s, and I knew Marion would be as sore as she could be. She had said I'm always late which is indeed substantially true. "I mean it. I don't want to appoint you. I just don't want to appoint you."

I said, "Yes, you told me that. You've made that perfectly clear. I understand that."

I was getting bored, really, when he whipped around on the telephone and said, "But unless you give me an unsurmountable objection I'm going to send your name in for the Court tomorrow at

10. P. 98 (quoting J. Farley, Jim FarLeY's Story 108 (1948)). 
twelve o'clock"- just like that, and I remember saying, and it is natural to remember this very vividly- "All I can say is that I wish my mother were alive."11

According to Michael Parrish, we are not to take Frankfurter's recollection of the January 4,1939 episode at face value: "This image of Frankfurter, clad only in undershorts, struck dumb by Roosevelt's change of heart, has a certain romantic appeal-but it's wholly false."12 Parrish goes on to say:

Joe Rauh, Jr., then one of Corcoran's assistants and later a Frankfurter law clerk, recalls a different version of events in December and January. Tommy the Cork kept the phone lines busy between Washington and Cambridge each evening, bringing his mentor up to date on the shifting battle scene. Corcoran and his supporters kept friendly senators supplied with damaging information about other potential candidates, and they organized an impressive letter-writing campaign on Frankfurter's behalf. Wavering senators, for instance, found their mailboxes stuffed with pro-Frankfurter wires from Harvard Law School alumni, old progressives, law professors, and leaders of local bar associations.

In addition to gaining the endorsement of Senator Norris, a key Westerner, the Corcoran forces received important support for Frankfurter from Hopkins, Robert Jackson, the new solicitor general, and Ickes, all of whom argued that Roosevelt might forever lose the opportunity to put his friend on the Court unless he did it now. "If you appoint Felix," Ickes told F.D.R., "his abilities and learning are such that he will dominate the Supreme Court for fifteen or twenty years to come. The result will be that probably after you are dead, it will still be your Supreme Court." Only Frankfurter, argued Jackson, had the legal resources "to face Chief Justice Hughes in conference and hold his own in discussion," a point reinforced by Justice Stone, who also urged F.D.R. to name Frankfurter, because he could help contain the wily chief justice. ${ }^{13}$

Soon after Frankfurter took his seat, Roosevelt made a fourth appointment: William O. Douglas, SEC Chairman and erstwhile Yale professor, to replace Justice Brandeis, who had retired.

And for a while it appeared that Black and Frankfurter would be joint leaders of a new nucleus of Justices-not yet a majority, but likely to become one. Notably, and expectably, they were apostles of judicial restraint.

In Coleman v. Miller, ${ }^{14}$ members of the Kansas Legislature sued in the

11. F. Frankfurter, Felix Frankfurter Reminisces 282-83 (H. Phillips ed. 1960).

12. M. PARRISH, supra note 5 , at 275 .

13. Id. at $275-76$ (footnotes omitted).

14. 307 U.S. 433 (1939). 
Kansas Supreme Court for a writ of mandamus directing various state officials not to certify to the Governor the 1937 ratification by the legislature of the Child Labor Amendment that Congress had submitted to the states in 1924. Plaintiffs contended that (1) a prior rejection of the amendment by the Kansas Legislature precluded later ratification; (2) the Lieutenant Governor, who had voted to break a Senate tie, was not a proper participant in the ratifying process contemplated by the Constitution; and (3) the amendment, proposed in 1924, had in any event long since lost all constitutional vitality. The Kansas Supreme Court entertained the application and denied it on its merits. The Supreme Court, on certiorari, affirmed by a vote of seven (Chief Justice Hughes and Justices Stone, Roberts, Black, Reed, Frankfurter, and Douglas) to two (Justices Butler and McReynolds). The opinion of the Court was written by Chief Justice Hughes, and was joined by Justices Stone and Reed. The opinion declared that (1) those plaintiffs-petitioners-legislators who had voted against ratification had standing to sue, (2) whether the Lieutenant Governor's participation was a "political question" committed to Congress rather than the courts was a matter on which the Court was equally divided, and (3) the other claims made were "political questions." Justice Black filed a concurrence, for himself and Justices Roberts, Frankfurter, and Douglas, challenging any intimation in the Chief Justice's opinion that any aspect of the ratification process was judicially reviewable. And Justice Frankfurter filed a separate opinion, for the same four Justices, taking issue with the holding that any of the plaintiffs-petitioners-legislators had standing to sue. ${ }^{15}$

In a very different context, Justice Frankfurter, in 1941, filed a dissent that sounded other notes of judicial caution for himself and Justices Black, Douglas, and Murphy. The case was Sibbach $v$. Wilson, ${ }^{16}$ and the issue was the validity of Federal Rule of Civil Procedure 35, authorizing court orders for the physical examination of a party to civil litigation. Frankfurter saw such an exercise of judicial authority as a substantial intrusion upon personal autonomy-and it was a form of authority that, prior to the Rules, the Federal courts concededly did not possess. Frankfurter did not doubt that Congress had power to vest Federal courts with such authority, but he was unpersuaded that such a significant departure from prior practice could be squared with the directive of the Rules Enabling Act that "[s]aid rules shall neither abridge, enlarge, nor modify the sub-

\footnotetext{
15. Justice Butler, writing for himself and Justice McReynolds, concluded that the proposed amendment, thirteen years old, was no longer viable. What remains a mystery is how the Court could have been equally divided on the "political question" status of the Lieutenant Governor's participation, given that four of the nine Justices had announced that all petitioners' claims were political questions; for the Court to be equally divided, one of the other five would have had to abstain with respect to the Lieutenant Governor issue, but no such abstention is noted in either the Hughes or the Butler opinion.

I6. 312 U.S. 1 (1941).
} 
stantive rights of any litigant."17 And Frankfurter rejected the Court's view that, since the Rules were laid before Congress before taking effect, the fact that "no adverse action was taken by Congress indicates . . . that no transgression of legislative policy was found."18 In the view of the dissenters, "[h]aving due regard to the mechanics of legislation and the practical conditions surrounding the business of Congress when the Rules were submitted, to draw any inference of tacit approval from non-action by Congress is to appeal to unreality."19

The dissenting unity evidenced in these cases translated into a strong majority in the first major civil liberties case to reach the Court after Frankfurter's appointment. The case was Gobitis, ${ }^{20}$ in which Frankfurter, writing for every member of the Court but Stone, sustained a compulsory public school flag salute challenged by Jehovah's Witness children as requiring of them the sacrilege of obeisance to a symbol which was not divine. Douglas signed on to the opinion with this encomium: "The Court is indebted to you.' . . 'This is a powerful moving document of incalculable contemporary and (I believe) historic value. I congratulate you on a truly statesmanlike job.' "21 But outside the Court the response was chilly, especially in those quarters of liberal opinion which had for so many years looked to Professor Frankfurter for leadership. And, as Simon tells us, the unity within the Court quickly eroded. Later in 1940, Douglas revisited the Gobitis problem in a conversation with Frankfurter that the latter memorialized in his scrapbook:

"Hugo thinks maybe we made a mistake in Gobitis."

"Has Hugo been reading the Constitution?"

"No, he's been reading the newspapers . . . ."22

Two years later, Black, Douglas, and Murphy filed a dissent in another Jehovah's Witness case announcing their revisionist view that Gobitis was wrongly decided. And, with the appointment to the Court of two new Justices-Jackson and Rutledge-the stage was set for the overruling of Gobitis. The vehicle was West Virginia Board of Education v. Barnette, ${ }^{23}$ decided on Flag Day, 1943, in the midst of World War II. Jackson wrote the Court's opinion. Only Roberts and Reed stayed with Frankfurter. The depth of Frankfurter's distress can be gauged by the opening paragraph of his celebrated dissent. According to Max Freedman,

17. Federal Rules Enabling Acts, ch. 651, 48 Stat. 1064 (1934) (codified as amended at 28 U.S.C. $\$ 2072$ (1982)).

18. 312 U.S. at 16

19. Id, at 18 .

20. Minersville School Dist. v. Gobitis, 310 U.S. 586 (1940).

21. P. 111 (quoting from Felix Frankfurter papers, Harvard Law School).

22. P. 115 (quoting from H. Hirsch, The Enigma of Felix Frankfurter 152 (1981)).

23. 319 U.S. 624 (1943). 
two members of the Supreme Court, who need not be identified here, called formally on Frankfurter in his Chambers to plead with him to omit or soften this opening paragraph. They said it was too emotional and too personal for inclusion in a Supreme Court opinion. Frankfurter said they had given him very good reasons for taking these words out, but he had even better reasons for keeping them in ....24

The paragraph follows:

One who belongs to the most vilified and persecuted minority in history is not likely to be insensible to the freedoms guaranteed by our Constitution. Were my purely personal attitude relevant I should wholeheartedly associate myself with the general libertarian views in the Court's opinion, representing as they do the thought and action of a lifetime. But as judges we are neither Jew nor Gentile, neither Catholic nor agnostic. We owe equal attachment to the Constitution and are equally bound by our judicial obligations whether we derive our citizenship from the earliest or the latest immigrants to these shores. As a member of this Court I am not justified in writing my private notions of policy into the Constitution, no matter how deeply I may cherish them or how mischieyous I may deem their disregard. The duty of a judge who must decide which of two claims before the Court shall preyail, that of a State to enact and enforce laws within its general competence or that of an individual to refuse obedience because of the demands of his conscience, is not that of the ordinary person. It can never be emphasized too much that one's own opinion about the wisdom or evil of a law should be excluded altogether when one is doing one's duty on the bench. The only opinion of our own even looking in that direction that is material is our opinion whether legislators could in reason have enacted such a law. In the light of all the circumstances, including the history of this question in this Court, it would require more daring than I possess to deny that reasonable legislators could have taken the action which is before us for review. Most unwillingly, therefore, I must differ from my brethren with regard to legislation like this. I cannot bring my mind to believe that the "liberty" secured by the Due Process Clause gives this Court authority to deny to the State of West Virginia the attainment of that which we all recognize as a legitimate legislative end, namely, the promotion of good citizenship, by employment of the means here chosen. ${ }^{28}$

By the time Barnette was decided, Black's change of mind signified more than a disagreement with Frankfurter over one highly controversial

24. M. Freedman, supra note 2, at 701. According to Simon, at p. 118, Frankfurter's law clerk, Philip Elman, made the same point to the Justice, but also to no avail.

25. 319 U.S. at 646-47. For a reprise of Gobitis, Barmette, and related matters, see Pollak, The Republic for Which It Stands, 24 LAND \& WATER L. Rev. 565 (1989). 
issue. It signified a rejection of Frankfurter's leadership. And it further signified the beginning of Black's assumption of leadership of a voting bloc that included Douglas, Murphy, and, frequently but not uniformly, Rutledge. Happily, notwithstanding that the once-cordial FrankfurterDouglas relationship steadily deteriorated, Frankfurter and Black always remained friends. There were occasional strains, for Frankfurter was not above saying callous things about Black to third persons. But in its essentials the friendship endured, and indeed was to grow stronger-in considerable measure because the Frankfurters were devoted to Josephine Black (the Justice's first wife, who died in 1951) ${ }^{26}$ and to the Blacks' three children.

\section{The Intellectual Debate}

Simon's book is basically a narrative of the intellectual and institutional discord, and the personal concord, of Black and Frankfurter. To retell that narrative here would serve no useful purpose. But certain observations on a few of the highlights may be in order.

\section{A. Incorporation}

The Black-Frankfurter debate that glowed with most intensity was the question whether the protections of the Federal Bill of Rights are incorporated, as against the states, into the Fourteenth Amendment. Before Frankfurter came to the Court, Black, the junior Justice, had joined Cardozo's last great opinion, Palko v. Connecticut. ${ }^{27}$ Palko rejected appellant's claim that, via the Fourteenth Amendment, the Fifth Amendment's ban on double jeopardy invalidated a Connecticut statute under which the state, after successfully appealing errors committed at a trial which resulted in a second degree murder conviction and a life sentence, had tried appellant again, this time getting a first degree murder conviction and a death sentence. Cardozo rejected any "general rule" of absorption of all of the enumerated rights of the Bill of Rights into the due process clause of the Fourteenth Amendment. He catalogued those Federal rights that the Court had held were not binding on the states-for instance, the grand jury-and compared them with those that were-such as "freedom of thought, and speech, ... the matrix, the indispensable condition, of nearly every other form of freedom," and "the thought that condemnation shall be rendered only after a real [hearing], not a sham or a pretense."28 And from this comparison Cardozo distilled, as an organizing principle,

26. Six years later, Justice Black married Elizabeth DeMeritte. For her touching reminiscences, see E. BLACK, supra note 5.

27. 302 U.S. 319 (1937).

28. Id. at 326-27 (citations omitted). 
the question whether a particular right was "of the very essence of a scheme of ordered liberty."29

Six years later, in Adamson v. California ${ }^{30}$ Black in dissent repudiated Palko. In order to demonstrate that the defendant's California murder conviction was vitiated by the prosecutor's comments on his failure to take the stand, Black argued that the California rule contravened the Fifth Amendment's privilege against self-incrimination, and that the privilege, and all other rights enshrined in the Bill of Rights, were intended by the Congress which framed the Fourteenth Amendment to be applicable to the states. Frankfurter, in a concurring opinion, joined issue with Black, and legal historians have since been examining the issue, with not-quite pellucid clarity. ${ }^{31}$

Revisiting the debate over forty years later, one is struck by the wisdom of observations ventured by Paul Freund just two years after Adamson:

The whole episode of the debate on the general meaning of the Fourteenth Amendment is unfortunate. The controversy magnifies differences and obscures agreements .... Moreover, as a controversy over the meaning of history the debate on the Fourteenth Amendment can hardly be resolved. Whatever the general language of the sponsors of the Amendment, they did not squarely address themselves to the question whether each and every enumerated right in the first eight amendments was carried into the Fourteenth; and much less can we find an answer in the views of the legislators who ratified in the states. ${ }^{32}$

And Professor Freund's more general comments-comments not tied just to Palko-Adamson-also deserve our respectful attention:

How can the professional, or indeed the lay, observer of the Court's work better understand the concord and discord that he finds? He can recognize that because of the Court's special position in relation to our political as well as social institutions, it perforce operates in more than one realm of values; and that to assess those values requires judicial art, not artfulness, He can strive to understand the pressures of advocacy and of personal preference and the defensive mechanism which these evoke in the judicial mind. He can endeavor to appreciate the complexities of judging before criticizing the simplicities of voting. He can refrain from assigning judges to appointed places in a heavenly choir, to tiers in a celestial hierarchy. By doing these things we can perhaps give point to the story of the Irish cleric

\footnotetext{
29. Id. at 325 .

30. 332 U.S. 46 (1947).

31. Compare, e.g., Fairman, Does the Fourteenth Amendment Incorporate the Bill of Rights? The Original Understanding, 2 STAN. L. Rev. 5 (1949) with Crosskey, Charles Fairman, "Legislative History," and the Constitutional Limitations on State Authority, 22 U. GHr. L. REv. 1 (1954).

32. P. Freund, On Understanding The Supreme Court 33-34 (1949).
} 
who was asked by a parishioner what the difference was between the cherubim and seraphim, and who answered, "I think that there was once a difference between them, but they have made it up."33

The message of the Irish cleric should be heeded, but it should not be permitted to obscure what Black, at least, felt was crucially at issue in Adamson. Black felt that to permit judges-even judges as perceptive as Gardozo, or Frankfurter, or himself-to construct constitutional norms on the basis of their perceptions of what constitutes "the very essence of a scheme of ordered liberty" was to give those non-elected, and hence nonaccountable, officials boundless license to define the scope of the Fourteenth Amendment as broadly or narrowly as they chose. Black may have been wrong in thinking that his Adamson formula would improve anything. ${ }^{34}$ But the problem of how to set limits on judicial ad hocness, without surrendering to a formulaic and undifferentiating per seness, remains a besetting one. Indeed, at the level of Supreme Court adjudication the problem may be more intractable today than it was when Black and Frankfurter wrestled with it. Since the Court currently considers on the merits so minuscule a fraction-far less than one percent-of the cases decided by the circuit courts of appeal, the Palko paradigm of case-by-case refinement of a constitutional principle is markedly harder to achieve. As Justice Scalia recently pointed out, " $[\mathrm{t}]$ he idyllic notion of 'the court' gradually closing in on a fully articulated rule of law by deciding one discrete fact situation after another . . . simply cannot be applied to a court that will revisit the area in question with great infrequency."35

\section{B. Points of Agreement}

Black and Frankfurter were in agreement on the two most important cases to come before the Court during their joint tenure. In both instances the fact of their agreement had a decisive impact on shaping the Court's decision.

\section{Korematsu v. United States}

The first case was Korematsu $v$. United States. ${ }^{36}$ The Court there sustained, by a vote of six to three, the World War II program for the relocation of Japanese-Americans residing on the west coast. Under the program, senior military commanders, operating pursuant to the loosest of

\footnotetext{
33. Id. at $42-43$.

34. See Kadish, Methodology and Criteria in Due Process Adjudication-A Surrey and Criticism, 66 YALE L.J. 319, 338-39 (1957).

35. Scalia, The Rule of Law as a Law of Rules, 56 U. CHr. L. Rev. 1175, 1178 (1989).

36. 323 U.S. 214 (1944); see also Ex parte Endo, 323 U.S. 283 (1944). A year before Korematsu, the Court had sustained a far less draconian directive-namely, a curfew for west coast Japanese Americans. Hirabayashi v. United States, 320 U.S. 81 (1943).
} 
Congressional authorizations, promulgated orders requiring United States citizens, and permanent resident aliens, of Japanese ancestry to leave their west coast homes and report to assembly centers, whence approximately 120,000 of them were shipped inland to internment centers. Failure to comply with the military orders was a crime. The Court majority consisted of Chief Justice Stone and Justices Black, Reed, Frankfurter, Douglas, and Rutledge. The dissenters-each of whom filed an opinion-were Justices Roberts, Murphy, and Jackson. Stone asked Black (apart from Stone, the senior member of the majority) to write the Court's opinion. Black's opinion undertook to treat the case as if the only aspect of the relocation program at issue was the exclusion order, that is, the requirement, which Fred Korematsu concededly violated, that he leave his home in San Leandro, California. The further requirement that Korematsu, on departing from San Leandro, report to an assembly center, with the probability of then being shipped to an internment camp, was beyond the Court's judicial vision. Black's opinion was, as Simon observes, "the worst judicial opinion that Justice Hugo Black wrote in his thirty-four years on the Court." 37 Frankfurter's concurring opinion was better only in the sense that it was shorter.

Korematsu is almost as completely discredited as Dred Scott..$^{38}$ Four decades later, on a showing that the Government brief in the Supreme Court misrepresented the facts said to establish the military necessity for the challenged orders, the convictions of Fred Korematsu and others were set aside. ${ }^{39}$ And in the Civil Liberties Act of 1988, which authorized modest reparations for those interned, Congress acknowledged that a

grave injustice was done to both citizens and permanent resident aliens of Japanese ancestry by the evacuation, relocation, and internment of civilians during World War II. ... . [T] These actions were carried out without adequate security reasons . . . and were motivated largely by racial prejudice, wartime hysteria, and a failure of political leadership. . . . For these fundamental violations of the basic civil liberties and constitutional rights of these individuals of Japanese ancestry, the Congress apologizes on behalf of the Nation. ${ }^{40}$

The six members of the Korematsu majority cannot be criticized for not intuiting in 1944 what was to remain hidden from courts and Congress alike for forty years. But the six Justices may properly be criticized for not being as sensitive to the manifestly grave constitutional issues

37. P. 155; see Rostow, The Japanese American Cases-A Disaster, 54 YALE L.J. 489 (1945).

38. Dred Scott v. Sandford, 60 U.S. (19 How.) 393 (1857).

39. Korematsu v. United States, 584 F. Supp 1406 (N.D. Cal 1984). The misrepresentation was not known to Government counsel, who evidently relied in good faith on the misinformation fed to them. See Karst, Japanese American Cases, in 3 Encyclopedia, supra note 8, at 1010, 1012; P. IRONS, JUSTICE AT WAR (1983).

40. Civil Liberties Act of 1988, Pub. L. No. 100-383, § 2(a), 102 Stat. 903 (1988). 
presented to the Court as were their three dissenting colleagues. It may be surmised that the myopia of Black and Frankfurter was compounded by the strong personal loyalty that each had for the President/Commanderin-Chief. But it is noteworthy that two of the three dissenters-Murphy and Jackson-had served Roosevelt as Attorney General, and the third-Roberts-had, at Roosevelt's request, conducted an inquiry into the unpreparedness at Pearl Harbor; none of the three was likely to be indifferent to the legitimate demands of national security in wartime.

With Korematsu one may compare The Steel Seizure Case, ${ }^{\mathbf{4 1}}$ decided eight years later. There, the Court considered executive action-the seizure of most of the nation's steel plants-taken by Secretary of Commerce Sawyer at the direction of President Truman. The Secretary acted to avoid a threatened work stoppage that would have jeopardized steel production required for the Korean War. The principal question was whether the seizure of the steel plants was authorized by statute. The case was decided by a vote of six to three-the same margin as that in Korematsu. But this time the decision went against the President/Commanderin-Chief. The Court's opinion was written by Black. Frankfurter wrote a concurrence, ${ }^{12}$ as did Jackson.

\section{Brown v. Board of Education}

The second case was Brown v. Board of Education. ${ }^{43}$ Simon relates in capsule form much of the inside-the-Court history first narrated in meticulous detail by Richard Kluger, ${ }^{44}$ and recently given a revisionist spin by Philip Elman. ${ }^{45}$ Quite properly we give major credit for the Court's unanimous decisions, both as to liability and as to remedy, to Earl Warren, whom President Eisenhower appointed to the Chief Justiceship, in succession to Fred Vinson, in 1953. If Vinson had not died, or if Eisenhower had not appointed a Chief Justice with the stature and strong moral purpose of Warren, the Court would almost surely have been badly divided in Brown. But even Warren could not have rounded up the votes and fashioned the opinions single-handedly. The strong support of Black and Frankfurter was essential.

Black-the former Klansman, and the only Justice from the Deep South-knew where his judicial duty lay long before Brown $I$ was decided. He said as much to his eldest son, Hugo Black, Jr., a rising Birmingham lawyer who was thinking of running for Congress. Justice

41. Youngstown Sheet \& Tube Co. v. Sawyer, 343 U.S. 579 (1952).

42. If Frankfurter's ties to Truman were weaker than those to Roosevelt, his ties to Secretary of State Dean Acheson, Truman's principal adviser in the Korean War, were not.

43. 347 U.S. 483 (1954) (Brown I); 349 U.S. 294 (1955) (Brown II).

44. R. KLuger, Simple Justice (1976).

45. Elman, The Solicitor General's Office, Justice Frankfurter, and Civil Rights Litigation, 100 Harv. L. Rev, 817 (1987). But of. Kennedy, A Reply to Philip Elman, 100 HARv. L. Rev. 1938 (1987). Elman was Frankfurter's law clerk in the early 1940's. See supra note 24. 
Black told young Hugo that cases on the Court's docket might be decided in a way that would complicate his political future:

"I've got to tell you something in strictest confidence that has a lot to do with your decision." "What's that, Daddy?" "We've got some cases up before us where they are challenging segregation of the races. I agree with old Justice Harlan's dissent in Plessy v. Ferguson. I don't believe segregation is constitutional." "I think you are right, Daddy."46

For Frankfurter-an early adviser to the NAACP, and mentor of both Charles $\mathrm{H}$. Houston and William $\mathrm{H}$. Hastie-the answer was just as clear. As Frankfurter clerk William T. Coleman, Jr., has written, "Frankfurter's commitment to racial equality was absolute." tice, even before Vinson's death, had begun the missionary work that would narrow differences and, ultimately, achieve unanimity. It was Frankfurter who framed the questions that were the predicate of the 1953 reargument, ${ }^{48}$ who contrived to bifurcate liability and remedy, and who contributed "all deliberate speed." In retrospect, it is easy to say that Frankfurter should have known that "all deliberate speed" would invite southern foot-dragging and, then, bitter-end resistance. But, as Simon points out, what Frankfurter was institutionally entitled to expect-a strong voice from the White House supportive of the Court-was not forthcoming. "The times demanded the presidential leadership of a Lincoln or an Andrew Jackson, Frankfurter observed privately, and regrettably Dwight Eisenhower had neither the will nor the vision to meet the challenge." 49

\section{Conclüsion}

Simon's book is partly about law made by the Supreme Court. It is partly about friendship on that Court. And it is also about colleagueship among members of the Court: a structure for, and process of, working together that is indispensable to the proper functioning of that Court or, indeed, any appellate tribunal that takes its work seriously.

After Frankfurter, partly disabled by a stroke in 1962, retired from the Court, Black wrote him that "We're going to miss you on the Court because we need you," adding that "when some of my friends say to me,

46. H. BLACK, JR., supra note 5, at 208.

47. Coleman, Mr. Justice Frankfurter: Civil Libertarian as Lawyer and Justice: Extent to Which Judicial Responsibilities Affected His Pre-Court Convictions, in Six Justices on Crvil Rights 85, 102 (R. Rotunda ed. 1983). Coleman was Frankfurter's law clerk in the 1948 Term.

48. Frankfurter's strong right arm in this aspect of the endeavor was his law clerk, Alexander M. Bickel. See R. Kluger, supra note 44 , at 614-15.

49. P. 226. 
'things will be easier on the Court now,' I tell them they couldn't be more wrong."

This story complements an anecdote that Anthony Lewis tells in Gideon's Trumpet, the splendid book which traces the background of Gideon v. Wainwright. ${ }^{\text {s1 }}$ Gideon was the 1963 decision requiring, as an ingredient of Fourteenth Amendment due process, that states see to it that all felony defendants have counsel. Gideon overruled Betts v. Brady, ${ }^{62}$ a 1942 decision in which the majority, in a Roberts opinion joined by Frankfurter, held that counsel need be appointed only when there was a showing of "special circumstances" establishing the inability of the defendant adequately to represent himself. Black had written a masterful dissent in Betts v. Brady. And the Betts v. Brady rule proved unworkable, because there are almost always "special circumstances." Twenty-one years later it fell to Black to write the Court's opinion in Gideon, writing into the Constitution his earlier dissent. Lewis reports the following:

Gideon v. Wainwright was a triumph for Hugo Black, but in a way the case suggests that there was not always so deep a gulf between his view of the law and Felix Frankfurter's as the occasional ferocity of their well-known debate suggested. . . .

Shortly after the Gideon case was decided, Justice Black visited Justice Frankfurter at home and told his ailing colleague about the conference at which the case had been discussed. He had told the other members of the Court, Justice Black said, that if Felix had been there he would have voted-faithful to his own view of due process-to reverse the conviction of Clarence Earl Gideon and overrule Betts v. Brady. Justice Frankfurter said: "Of course I would."\$3

Simon's book closes with the following paragraph:

During the Court's winter break in February 1965, Hugo and Elizabeth Black [the Justice's second wife] ${ }^{54}$ visited Hugo Black, Jr., and his family in Miami. Afterward, Justice Black and his wife began the drive north toward Washington, D.C., stopping for breakfast in St. Augustine, Florida. At the breakfast table Hugo opened the morning's newspaper and gasped at the headline: "Ohhh, Felix is dead!" And then he wept. ${ }^{\text {ss }}$

50. P. 258 (quoting from Hugo Black papers, Library of Congress).

51. 372 U.S. 335 (1963).

52. 316 U.S. 455 (1942).

53. A. Lewis, Gideon's TRUMPet 220-22 (1964).

54. Ser supra note 26.

55. P. 260 (quoting from H. BLACK, JR. \& E. BLACK, supra note 5, at 102). 
